\title{
Synergistic Effects of Rooted Aquatic Vegetation and Drift Wrack on Ecosystem Multifunctionality
}

\author{
Å. N. Austin, ${ }^{1 *} \odot$ J. P. Hansen, ${ }^{2}$ S. Donadi, ${ }^{3}$ U. Bergström, ${ }^{4}$ B. K. Eriksson, ${ }^{5}$ \\ G. Sundblad, ${ }^{3}$ and J. S. Eklöf ${ }^{1}$
}

${ }^{1}$ Department of Ecology, Environment and Plant Sciences, Stockholm University, 10691 Stockholm, Sweden; ${ }^{2}$ Stockholm University Baltic Sea Centre, 10691 Stockholm, Sweden; ${ }^{3}$ Department of Aquatic Resources, Institute of Freshwater Research, Swedish University of Agricultural Sciences, Staingholmsvägen 2, 17893 Drottningholm, Sweden; ${ }^{4}$ Department of Aquatic Resources, Institute of Coastal Research, Swedish University of Agricultural Sciences, Skolgatan 6, 74242 Öregrund, Sweden; ${ }^{5}$ Groningen Institute for Evolutionary Life-Sciences (GELIFES), University of Groningen, Nijenborgh 7, 9747 AG Groningen, The Netherlands

\begin{abstract}
Ecosystem multifunctionality is an increasingly popular concept used to approximate multifaceted ecosystem functioning, which in turn may help advance ecosystem-based management. However, while experimental studies have shown a positive effect of diversity on multifunctionality, observational studies from natural systems-particularly aquatic-are scarce. Here, we tested the relative importance of species richness and cover of rooted aquatic vegetation, as well as cover of the looselying form of the macroalgae bladderwrack (Fucus vesiculosus), for ecosystem multifunctionality in shallow bays along the western Baltic Sea coast. We estimated multifunctionality based on four indicators of functions that support ecosystem services: recruitment of large predatory fish, grazer biomass, inverted 'nuisance' algal biomass, and water clarity. Piecewise path analysis showed that multifunc-
\end{abstract}

Received 26 June 2020; accepted 20 January 2021; published online 22 March 2021

Supplementary Information: The online version contains supplementary material available at (https://doi.org/10.1007/s10021-021-0060 9-9).

Author Contributions: ÅNA and JSE developed the idea, and ÅNA contributed to the laboratory work and analyzed the data with assistance from JPH, JSE and DS. ANA made the figures and wrote the manuscript. All authors helped design the field survey, contributed to the field work and revised previous versions of the manuscript.

*Corresponding author; e-mail: asa@austin.se tionality was driven by high cover of rooted aquatic vegetation and bladderwrack, particularly when the two co-occurred. This synergistic effect was nearly three times as strong as a negative effect of land-derived nitrogen loading. Species richness of aquatic vegetation indirectly benefitted multifunctionality by increasing vegetation cover. Meanwhile, high bladderwrack cover tended to decrease vegetation species richness, indicating that bladderwrack has both positive and negative effects on multifunctionality. We conclude that managing for dense and diverse vegetation assemblages may mitigate effects of anthropogenic pressures (for example, eutrophication) and support healthy coastal ecosystems that provide a range of benefits. To balance the exploitation of coastal ecosystems and maintain their multiple processes and services, management therefore needs to go beyond estimation of vegetation cover and consider the diversity and functional types of aquatic vegetation.

Key words: Ecosystem functions; Aquatic vegetation; Drift algae; Structural equation modeling (SEM); Diversity; Baltic Sea. 


\section{Highlights}

- Different aquatic vegetation types jointly drive ecosystem multifunctionality (MF).

- Vegetation species richness indirectly increases MF by enhancing vegetation cover

- Favoring diversity may counteract a negative effect of eutrophication on MF

\section{INTRODUCTION}

The management of natural systems is challenged by the global erosion of biodiversity, which threatens ecosystem processes and services on a planetary scale (Steffen and others 2015). These changes have led to a demand for a more holistic management perspective grounded in integrated ecosystem assessments (Levin and others 2009). An increasingly common approach to quantify the integrated functioning of ecosystems is the estimation of 'ecosystem multifunctionality' (hereafter 'multifunctionality') or the simultaneous provisioning of multiple ecosystem processes (Hector and Bagchi 2007). Multifunctionality estimations can be based on any ecosystem processes but have mainly been used to quantify the simultaneous performance of multiple ecosystem functions (that is, processes that support ecosystem services) and/ or ecosystem services (Manning and others 2018; Garland and others 2020). Consequently, while multifunctionality is rarely considered in natural systems today, its specific objectives may offer important advances in ecosystem management (Manning and others 2018), where the overarching goal is to balance human use of natural resources to maintain ecosystem structure and processes and, indirectly, the services they support.

All species differ in their contribution to different ecosystem processes; therefore, species richness has often been found to correlate positively with multifunctionality (Hector and Bagchi 2007; Gamfeldt and others 2008; Zavaleta and others 2010; Isbell and others 2011; Maestre and others 2012; Byrnes and others 2014; Soliveres and others 2016). Several studies suggest that the effect of biodiversity (often estimated as species richness) on multifunctionality is different, and possibly stronger, than the effect on single functions (Hector and Bagchi 2007; Gamfeldt and others 2008; Meyer and others 2018; but see Gamfeldt and Roger 2017). Positive biodiversity effects on multifunctionality have been found in a large number of terrestrial and aquatic experiments, but with weaker effects among primary producers than among herbivores (Lefcheck and others 2015). Yet, there is limited knowledge of how pervasive the biodiversitymultifunctionality relationship is in natural systems, particularly in aquatic environments (Soliveres and others 2016).

Aquatic vegetation (that is, rooted plants and macroalgae) can be foundation species in shallow ecosystems and sustain a wide array of ecosystem functions that support ecosystem services, such as sediment stabilization (Madsen and others 2001; Scheffer 2004; Austin and others 2017), nutrient and carbon storage (McGlathery and others 2007; Wang and others 2016), and primary and secondary production (Duarte 2000). In many parts of the world, however, aquatic vegetation species are threatened by near-shore development, eutrophication, and cascading effects of overfishing (Lotze and others 2006; Orth and others 2006; Waycott and others 2009). Long-term efforts to reduce nutrient loads have led to partial or full recovery of aquatic plants both in some estuarine (for example, Lefcheck and others 2018) and shallow freshwater ecosystems (Sand-Jensen and others 2008), showing that concentrated management actions may reverse these negative trends. In Chesapeake Bay (USA), the recovery of aquatic plants was greatest in the less saline areas where more than a dozen aquatic plant species coexist and their species richness promoted increased plant cover (Lefcheck and others 2018). High species richness of aquatic vegetation has also been found to benefit seagrass restoration (Williams and others 2017), as well as the total cover and temporal stability of seaweed assemblages (Stachowicz and others 2008).

Drift algae are detached or naturally free-living macroalgae that are common in shallow coastal ecosystems (Valiela and others 1997). The term is often used to for ephemeral, filamentous taxa favored by eutrophication (Fletcher 1996), which are often seen as a nuisance because they (1) house lower abundance of fish in comparison with other types of vegetation (Deegan and others 2002), (2) compete for light and/or space with attached and habitat-forming vegetation like perennial plants or attached macroalgae, and (3) accumulate and decompose on beaches and in shallow areas, contributing to low-oxygen conditions (Hauxwell and others 2001; Berglund and others 2003). In northern Europe, common taxa that can occur as drift algae are fucoids (that is, Fucus spp.) commonly referred to as 'wrack.' One example is Fucus vesiculosus, a brown seaweed normally growing attached to rocks, shells or bedrock in wave-exposed areas. In the Baltic Sea (N Europe), F. vesiculosus can 
also be found growing loose-lying in sheltered sediment areas and there sometimes form dense mats. This particular growth form of $F$. vesiculosus was first described in 1901 (Svedelius 1901), and was in 2013 designated as a special biotope for protection (HELCOM 2013a). In the NE Atlantic similar types of drift wrack have been found to disturb seagrasses and seagrass restoration by shading, causing anoxic conditions and through uprooting and burial of shoots (Valdemarsen and others 2010; Moksnes and others 2018). Although the regular attached Fucus spp. provide important habitat for fish spawning, juvenile fish and their prey (Dempster and Kingsford 2004; Wikström and Kautsky 2007; Snickars and others 2010), knowledge of the functional role of the drift wrack is currently lacking.

The aim of this study was to disentangle the relative importance of species richness and cover of rooted aquatic vegetation, cover of drift wrack (Fucus vesiculosus, hereafter 'bladderwrack') and abiotic conditions, on ecosystem multifunctionality in a natural, coastal ecosystem. We conducted a field survey in 32 shallow coastal bays in the western Baltic Sea along natural (wave-exposure, bay openness and size) and anthropogenic gradients (land-derived nutrient load) known to strongly influence shallow bay ecosystems (Hansen and others 2008; Snickars and others 2009; Rosqvist and others 2010; Donadi and others 2017). In August and early September, right after ecosystem productivity peaks (Wijnbladh and Plantman 2006), we measured four indicators of key ecosystem functions known to be influenced by aquatic vegetation-recruitment of large predatory fish (as abundance of young-of-the-year perch Perca fluviatilis and pike Esox lucius), algal grazer biomass (biomass of invertebrate mesograzers), 'nuisance' algal biomass (inverted filamentous algal biomass per vegetation biomass), and 'water clarity' (inverted turbidity) - and used these to estimate multifunctionality. Previous studies show that (1) the abundance of juvenile pike increases with cover of (especially rooted) vegetation, while abundance of juvenile perch peaks at $40-80 \%$ cover (Hansen and others 2019); (2) the biomass of algal-feeding grazers increases with vegetation cover and in turn suppresses filamentous algae (Duffy and others 2013; Donadi and others 2017); (3) filamentous algae cover can be suppressed by competition with dense vegetation (Krause-Jensen and others 2008; Werner and others 2016; Donadi and others 2018); and (4) high vegetation cover can increase water clarity (Boer 2007; Austin and others 2017) through competition with phyto- plankton by uptake of dissolved nutrients (Le Bagousse-Pinguet and others 2012) and through sediment stabilization and deposition (Agawin and Duarte 2002).

Based on theories of the influence of biodiversity on multifunctionality as well as system-specific drivers and responses (see above), we hypothesized that multifunctionality in shallow coastal bays is positively influenced by high diversity and cover of aquatic vegetation (which are in turn influenced by environmental factors like the size and topographic openness of the bays), and therefore may counteract a negative influence of nutrient loading (eutrophication). Moreover, because rooted vegetation and drift wrack (free-living Fucus vesiculosus) differ greatly in traits like morphology, their cooccurrence might benefit multifunctionality through a complementarity effect, evident as a synergistic interaction. To tease apart these direct and indirect drivers of multifunctionality we used piecewise path analysis, a form of structural equation modeling (SEM) (Shipley 2000; Grace and others 2010). Following standard procedure in SEM we outline the specified interactions ('paths') and their prior support in the Methods section. Finally, we also tested the robustness of the overall results for changes in the relative contribution of each of the four 'processes' to multifunctionality, using a weighted averages approach.

\section{MeTHODS}

\section{Study System}

The Baltic Sea is a large $\left(377,000 \mathrm{~km}^{2}\right)$ brackish marginal sea in northern Europe, with some of the largest archipelagos in the world with thousands of islands and shallow, wave-sheltered bays (Figure 1). The bays often house abundant and diverse assemblages of aquatic vegetation and macroinvertebrates of both marine and freshwater origin (Hansen and others 2008; Rosqvist and others 2010). The bays are also important spawning and nursery grounds for coastal fish due to rapid warming of the water during spring, where several fish species lay their eggs and use the aquatic vegetation for foraging and shelter (Snickars and others 2009; Hansen and others 2019). However, the Baltic Sea and its archipelagos are highly affected by anthropogenic activities such as eutrophication (Elmgren 1989; Gustafsson and others 2012) and coastal exploitation (Sundblad and Bergström 2014; Hansen and others 2019), which is why these vegetated habitats are threatened and targets for conservation (HELCOM 2013b). 
The vegetation community in the shallow wavesheltered (soft-bottom) bays of the Baltic Sea consists of a total species pool of ca 15-40 plants and perennial, non-filamentous macroalgae (depending on region, Hansen 2016), of which pondweeds (Potamogeton/Stuckenia), milfoils (Myriophyllum), stoneworts (Chara) and (in some areas) dense mats of loose-lying Fucus vesiculosus dominate. Moreover, many bays harbor high abundances of filamentous algae, mainly as attached epiphytes or loose-lying, with Cladophora glomerata dominating (Hansen and others 2008).

\section{Field Survey}

The field survey was performed in August and early September 2014 in 32 shallow bays along $360 \mathrm{~km}$ of the central Swedish Baltic Sea coast (Figure 2). The bays were chosen to form gradients in topographic openness and land-derived nutrient load, and were situated more than $10 \mathrm{~km}$ apart (water distance) to ensure that fish communities were independent based on connectivity and migration (Saulamo and Neuman 2002; Berkström and others 2019).

The water surface area $\left(a, \mathrm{~m}^{2}\right)$ of each bay was estimated from satellite images in Google Earth Pro (Version 7.1.5.1557), and ranged from 0.4 to 25 ha (mean: 5.5 ha). Topographic openness (Ea, dimensionless) was estimated as $E a=100 * A t / a$, where $A t$ is the smallest cross-sectional area $\left(\mathrm{m}^{2}\right)$ connected to the sea (calculated from field mea- surements of inlet depth and satellite image-derived width) (Persson and others 1994). Modeled data of land-derived nutrient load $\left(\mathrm{kg}_{\mathrm{g}}\right.$ year $\left.{ }^{-1}\right)$ from watersheds surrounding each bay were derived from the Swedish Meteorological and Hydrological Institute's database 'SVAR' [version 2012_2] and 'S-HYPE' model [version 2012_1_2_1] (Arheimer and others 2012).

Within each bay, sampling was conducted at 6-9 stations, with higher replication in larger bays. To gain a representative sampling of the whole bay area, the stations were distributed at least $30 \mathrm{~m}$ apart across the bay at $0.5-3.5 \mathrm{~m}$ depth. The stations were marked with weighted buoys. We first sampled water for turbidity. Water was sampled at $0.5 \mathrm{~m}$ depth, stored dark and cold for ca. $6 \mathrm{~h}$ until turbidity was measured using a handheld turbidimeter (Aquafluor ${ }^{\circledR}$, Turner Designs, USA). The average turbidity (NTU) was calculated from 3 measurements per station. After the water sampling we took a break on land to reduce disturbance on fish. Second, we sampled young-of-theyear (YOY) fish using small underwater detonations (non-electric $1 \mathrm{~g}$ charge igniting a $10 \mathrm{~g}$ primer), which kills or stuns fish within a ca. $5 \mathrm{~m}$ radius (ca. $80 \mathrm{~m}^{2}$ ) (Snickars and others 2007; Sundblad and others 2014). The point of the detonation was directly marked with a weighted buoy, and floating fish were then netted and sunken fish collected by a snorkeler. YOY perch (Perca fluviatilis) and pike (Esox lucius) were identified and counted,

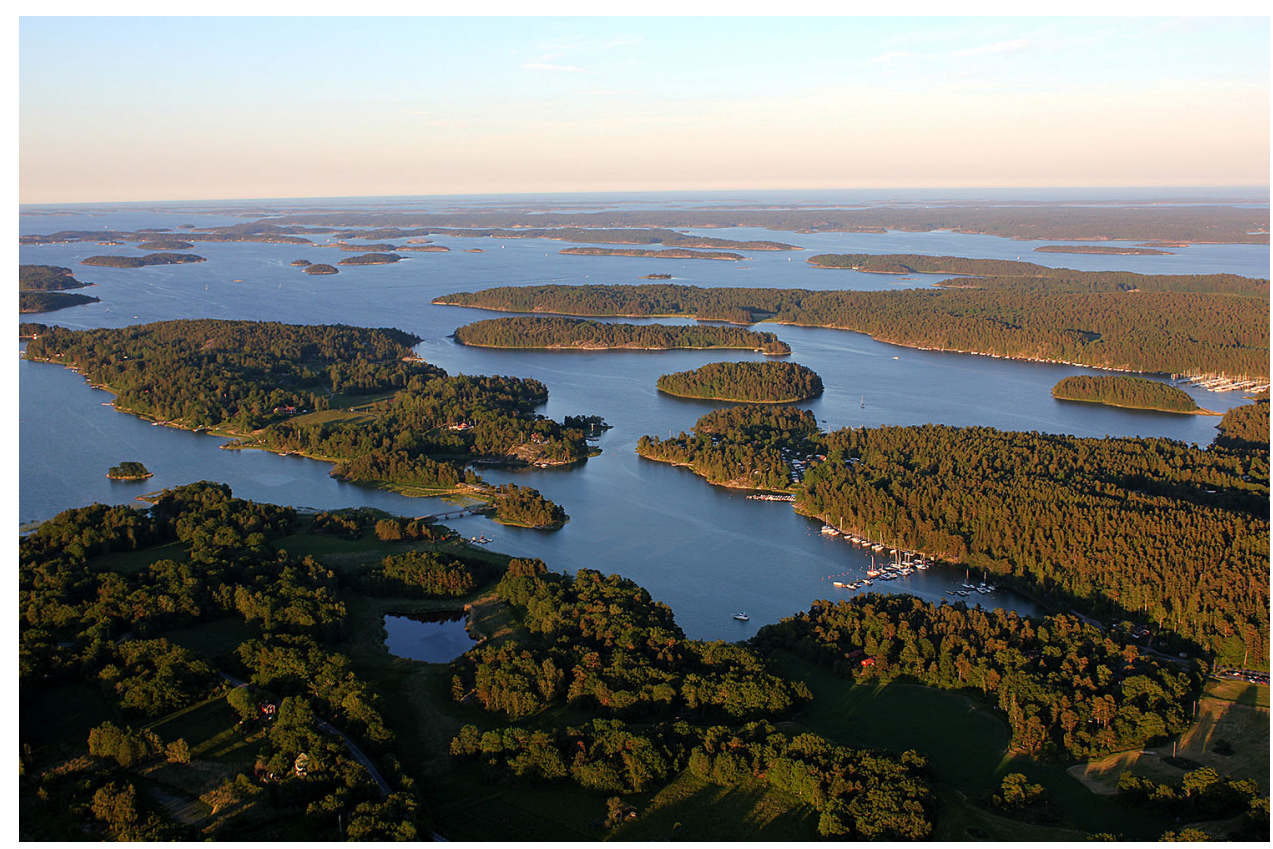

Figure 1. Swedish Baltic archipelago from above. Photo: Joakim Hansen. 


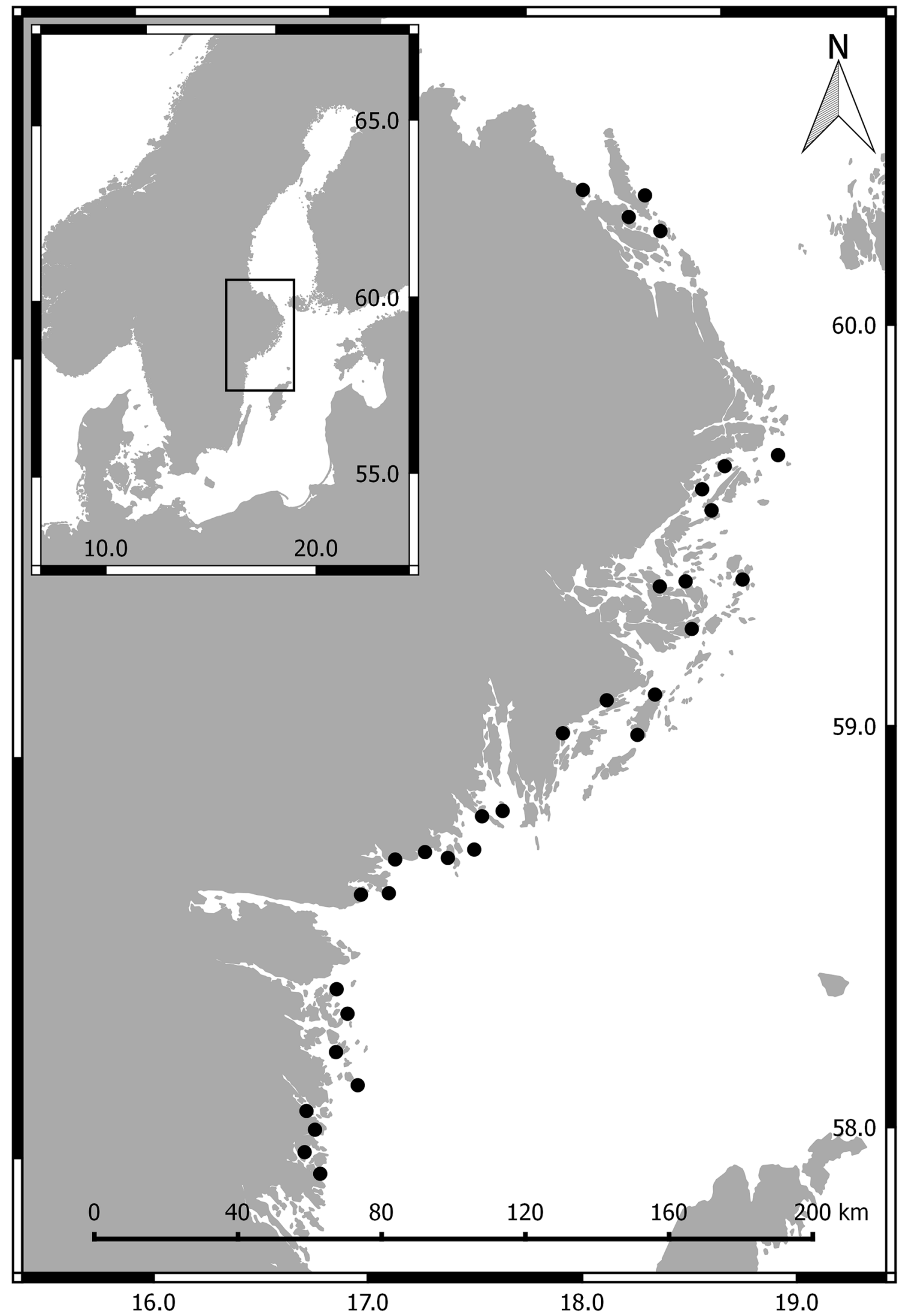


4Figure 2. Study area along the Swedish central Baltic Sea coast. Black dots are the locations of the 32 sampled bays. Axis labels are latitude (N) and longitude (E).

and their sum expressed as number of juvenile large predatory fish per sample.

Third, the cover of benthic vegetation was surveyed within $5 \mathrm{~m}$ of the buoy marking the detonation. The cumulative \% cover of all macroscopic vegetation species was visually estimated by a snorkeler within five randomly placed $0.5 \times 0.5 \mathrm{~m}$ frames $\left(0.25 \mathrm{~m}^{2}\right.$, Figure 3) (for a more detailed description, see Austin and others 2017). The rooted vegetation was dominated by the angiosperms Stuckenia pectinata, Potamogeton perfoliatus and Myriophyllum spicatum (Table S1). We here also classified Characeans (Chara baltica being the most common) as rooted, because of their similar growth form and root-like rhizoids. Adding bladderwrack, this classification captured 23 of 27 habitat-forming species occurring in the 32 bays (Table S1). Nearly all bladderwrack was loose-lying (for example, $80 \%$ of observations were in areas with pure sediment bottom, and $95 \%$ in areas with sedimentdominated bottoms). Species richness of the rooted vegetation was estimated as $\alpha$-diversity, that is, the mean rooted species richness per station for each bay.

Finally we sampled vegetation including filamentous algae (mainly epiphytic) and associated macroinvertebrates within a randomly placed $0.2 \times 0.2 \mathrm{~m}$ frame $\left(0.04 \mathrm{~m}^{2}\right)$, with a $1 \mathrm{~mm}$-mesh bag attached. In the laboratory, 3-8 samples from each bay were analyzed. First, filamentous algae and macroinvertebrates were separated from the vegetation. The mean dry biomass of filamentous algae and vegetation per station were determined after drying at $60{ }^{\circ} \mathrm{C}$ for $48 \mathrm{~h}$. The macroinvertebrates were identified, their body length measured and their biomass estimated as gram ash-free dry mass per sample $\left(0.04 \mathrm{~m}^{2}\right)$ using taxon-specific correlations between length and ash-free dry mass (Eklöf and others 2017).

\section{Estimation of Ecosystem Multifunctionality}

After averaging all station-level variables per bay $(\mathrm{N}=32)$ we estimated ecosystem multifunctionality based on four indicators of ecosystem functions, that is, processes that directly and indirectly support ecosystem services in shallow coastal areas of the Baltic Sea (HELCOM 2010). These were: (1) large predatory fish recruitment quantified as the

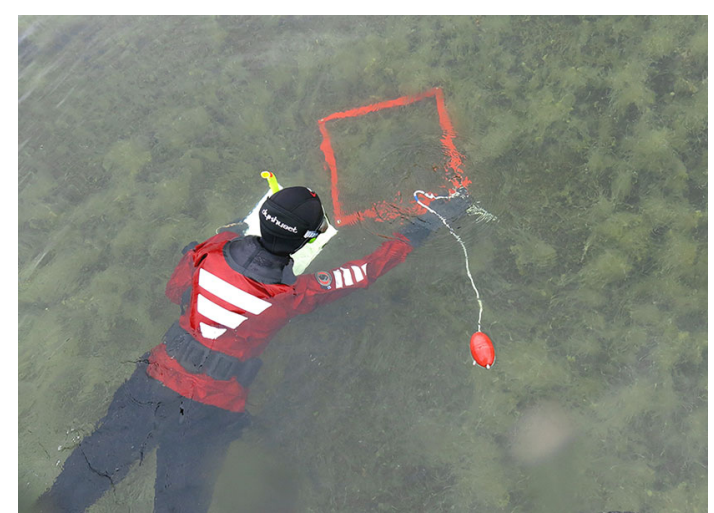

Figure 3. Visual estimation of vegetation cover by a snorkeler in one of the 32 bays. Photo: Joakim Hansen.

abundance of young-of-the-year (YOY) perch and pike, (2) grazer biomass (see Donadi and others 2017 Appendix D), (3) biomass of filamentous 'nuisance' algae quantified as the inverted biomass of filamentous algae per biomass of vegetation (which yields a ratio between $0-1$ ), and (4) water clarity, quantified as the reflected turbidity ($\mathrm{NTU}+\max (\mathrm{NTU}))$. Biomass of the filamentous algae and water turbidity were inverted and reflected, respectively, because high values of 'multifunctionality' should express the desirable level of the variable. The four indicators were standardized by dividing each variable by the average of its three highest values (yielding an overall multifunctionality range of $0.25-0.99)$. A correlation matrix of the average multifunctionality and the four indicators is shown in Figure Sl. Although multifunctionality can be estimated in several ways, we chose the 'averaging' approach (where multifunctionality is the mean of the included functions) because it is simple, intuitive and therefore easy to communicate. We refrained from using 'threshold' approaches (Byrnes and others 2014) because they are very sensitive to standardization method and the number of functions included (Gamfeldt and Roger 2017).

\section{Path Analysis}

To assess the direct and indirect drivers of multifunctionality we used piecewise path analysis (Shipley 2000; Grace and others 2010) as implemented in the piecewiseSEM package v. 2.0.2 (Lefcheck 2016) in R v. 3.5.2 (R Core Team 2018).

First, we formulated hypotheses about drivers of multifunctionality based on previous knowledge (Figure 4). We hypothesized that topographic openness (1) increases the species richness (Hansen and others 2008) and (2) decreases the cover of rooted 


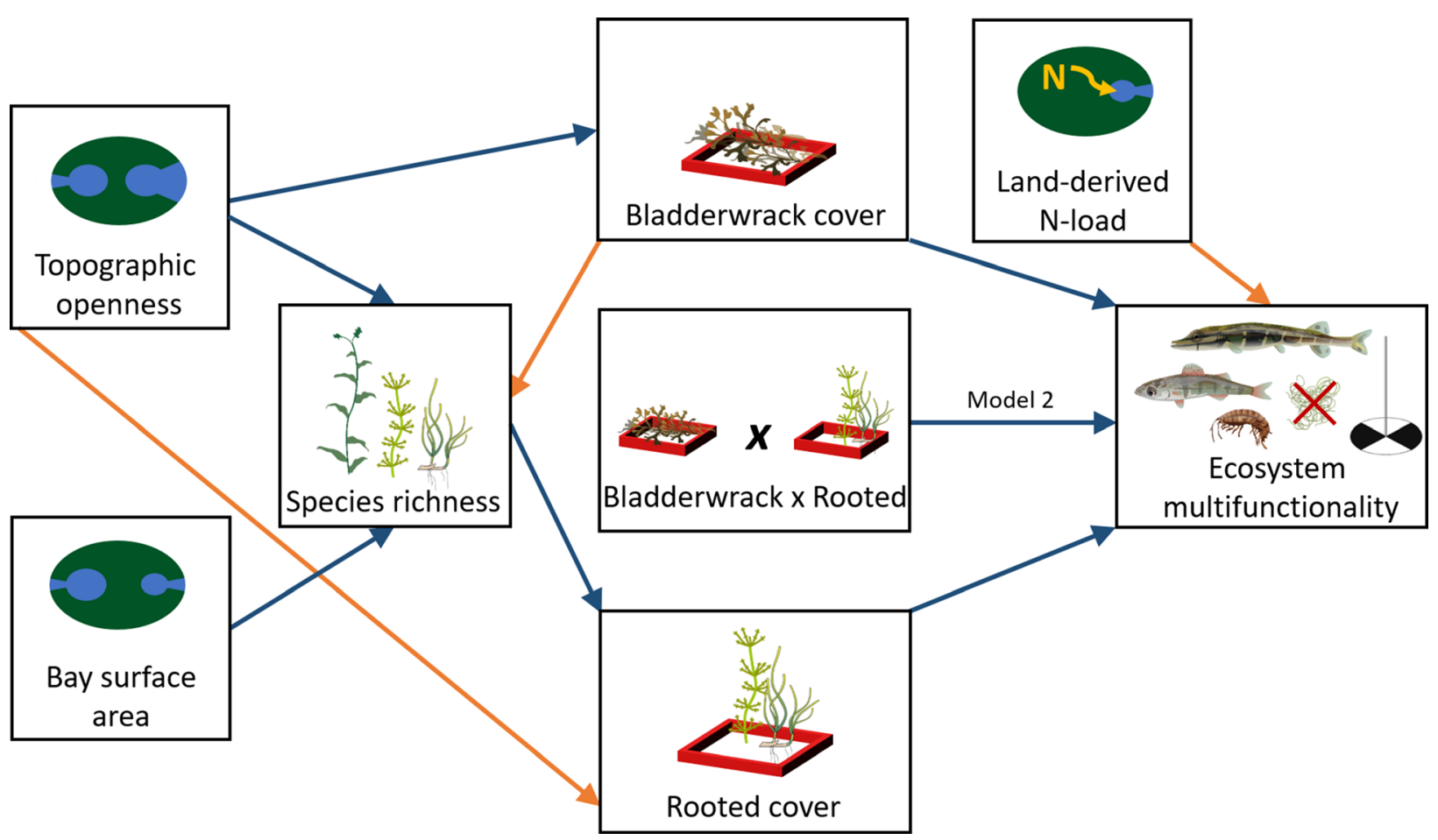

Figure 4. Conceptual model of the hypothesized relationships. Blue arrows indicate positive and orange arrows negative causal links. Model 2 includes an interactive effect between bladderwrack and rooted vegetation cover (as well as their individual effects) on ecosystem multifunctionality, whereas model 1 only includes the individual effects of bladderwrack and rooted vegetation cover, respectively, on ecosystem multifunctionality. Illustrations with contributions from the IAN Image Library (University of Maryland) and Pierre Drackner.

vegetation, and (3) increases the cover of drift wrack (Rosqvist and others 2010). These structural changes are a result of increased wave exposure and water exchange leading to decreased sedimentation and accumulation of fine organic particles, resulting in less nutrient-rich and more heterogeneous and coarser substrates, with increasing openness. In addition, open bays are more accessible to both drifting filamentous algae and bladderwrack than enclosed bays (Berglund and others 2003; Rosqvist and others 2010). We also hypothesized that (4) bay surface area increases the species richness of vegetation (Rosenzweig 1995), and that (5) land-derived nitrogen load has a direct negative effect on multifunctionality by increasing growth of phytoplankton (increasing turbidity) and ephemeral filamentous algae (for example, Schramm and Nienhuis 1996). We initially included a direct effect of land-derived nitrogen load on bladderwrack and rooted vegetation cover (negative eutrophication effect), but the relationship was not significant in any of the models (see also Austin and others 2017) and was therefore left out to decrease model complexity given the relatively low sample size. We focused on nitrogen $(\mathrm{N})$ rather than phosphorous $(\mathrm{P})$, as the ratio between the two elements suggested that most of the bays were $\mathrm{N}$-limited at the time of sampling (based on measured nutrient concentrations in the bays and the Redfield ratio; see Austin and others 2017). However, the modeled load of nitrogen and phosphorous were highly correlated in our data (Spearman rho $=0.96, p<0.0001$ ) Further, we hypothesized that the species richness of rooted vegetation (6) increases the total cover of rooted vegetation (Sanderson and others 2004; Williams and others 2017; Lefcheck and others 2018) but (7) is negatively affected by increased cover of loose-lying bladderwrack due to shading and competition for space (Valdemarsen and others 2010; Moksnes and others 2018). We initially also included a direct effect of bladderwrack on rooted vegetation cover, but this path was not significant in any of the models and was therefore removed. However, the upper limit of rooted vegetation cover seemed to be limited by high bladderwrack cover (Figure S2). Similar to many previous multifunctionality studies we initially also included a direct effect of species richness on multifunctionality (for example, Hector and Bagchi 2007), but 
the effect was not significant in any of the models and was therefore removed. Instead, we hypothesized that there was an indirect effect of vegetation species richness on multifunctionality mediated by increased vegetation cover (for example, Lefcheck and others 2018), a variable well known to affect many ecosystem processes. Finally, we hypothesized that (8) the cover of bladderwrack and rooted vegetation increases the average multifunctionality due to their habitat-forming characteristics, contribution to secondary production, ability to compete with filamentous algae and phytoplankton for nutrients and to increase sedimentation and decrease re-suspension of sediment (Agawin and Duarte 2002; Hansen and others 2008; Snickars and others 2009; Le Bagousse-Pinguet and others 2012; Austin and others 2017). The traits of the two vegetation types are very different; besides vast differences in basic morphology, a dense cover of bladderwrack completely covers the bottom, while a dense canopy cover of rooted vegetation leaves bare bottom between the individual basal shoots. Additionally, rooted vegetation species such as Myriophyllum spicatum, Potamogeton perfoliatus and Stuckenia pectinata can grow much taller $(2-3 \mathrm{~m}$, Figure 5) than bladderwrack ( $\leq 0.5 \mathrm{~m}$ ) and form complex canopies above it. This led us to hypothesize that the effect of the two vegetation types on multifunctionality might even be synergistic, rather than simply additive. We tested if the effects of bladderwrack and rooted vegetation cover on multifunctionality were additive or synergistic by comparing two separate SEMs: one including the additive effects of bladderwrack and rooted vegetation (model 1, Figure 4) and one also including their interaction (model 2, Figure 4). The models thus included three exogenous variables: (1) topographic openness $\left(\log _{10}\right.$-transformed to reduce skewness), (2) bay surface area (log-transformed to reduce skewness) and (3) land-derived nitrogen load ( $\log _{10}$-transformed to reduce skewness). The endogenous variables were (1) bladderwrack cover (average per bay), (2) rooted vegetation cover (average per bay), (3) species richness of rooted vegetation $(\alpha$-diversity, the mean richness per station per bay), and (4) average multifunctionality (per bay).

To better understand the underlying processes driving the multifunctionality, and to test the robustness of the results to changes in individual functions, we also estimated the drivers of weighted multifunctionality. We doubled the individual contribution of each function to the multifunctionality metric (from 25 to $50 \%$, using weighted means) in separate path models. Models including

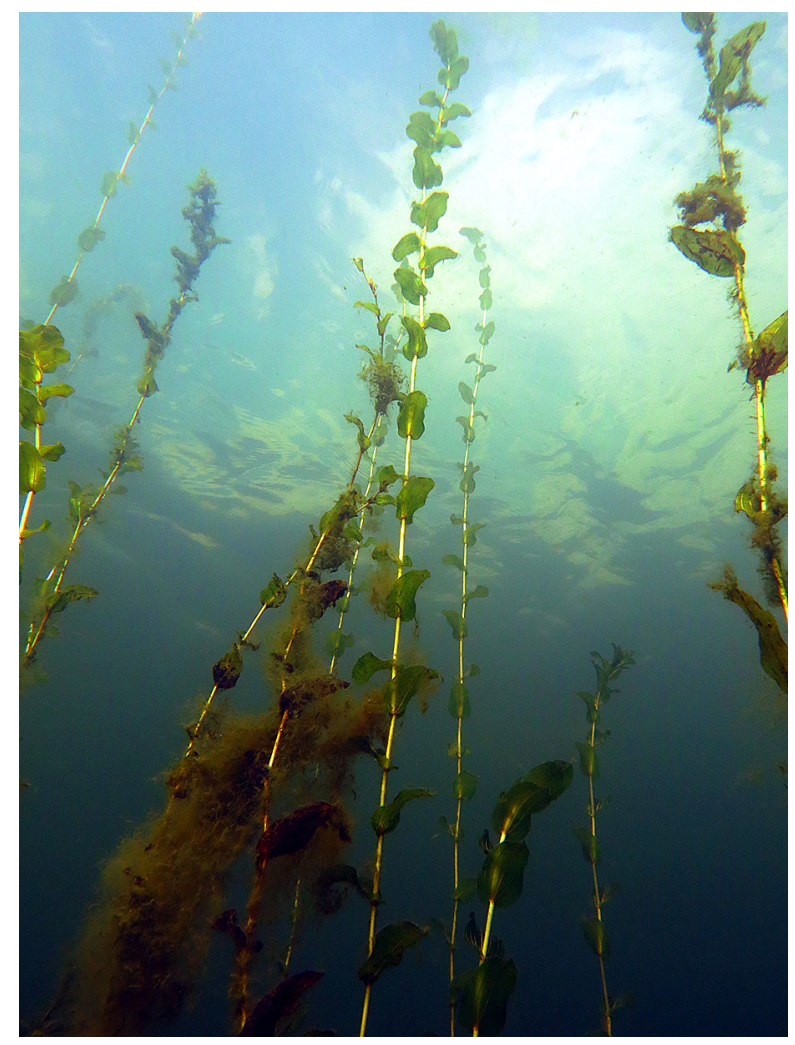

Figure 5. Shoots of perfoliate pondweed (Potamogeton perfoliatus) extending more than $2 \mathrm{~m}$ from the seabed. Photo: Joakim Hansen.

weighted multifunctionality were then compared to the two original path models in terms of their model fit (Akaike's Information Criterion, AIC) and effect sizes (that is, standardized coefficients) of the predictors of multifunctionality.

The distributions of all variables were examined graphically before model fitting. When normality assumptions were violated, a negative binomial error distribution with a log-link function was applied. Predictors were tested for multicollinearity by calculating the variance inflation factor $(\mathrm{VIF}<2$ ) and the correlation coefficients for all predictor combinations $(<0.63)$.

Model fit was assessed using the test of directed separation that produces a $\chi^{2}$-distributed Fisher's C statistic where models are indicated to fit the data when $p$ values are larger than 0.05 (Shipley 2009). We compared the models with and without the interaction between bladderwrack and rooted vegetation using AIC. Competing models with $\Delta$ AIC $<4$ were considered to fit the data equally well (Burnham and others 2011; Shipley 2013). To compare the relative strength of the significant paths, standardized coefficients were calculated using the latent-theoretical method developed for 
binomial response models (Grace and others 2018), which was adjusted for negative binomial distribution with log-link function by log-transforming the denominator $(\operatorname{sd}(\ln (\mathrm{Y}+1))$ (JB. Grace, pers. comm. in April 2020). Models were visually validated by plotting the residuals against the fitted values.

\section{Results}

Multifunctionality was best described by a combination of direct and indirect effects of bay morphology, species richness of vegetation, vegetation cover and nutrient loading. The model including the interaction between bladderwrack and rooted vegetation cover (model 2) fitted the data as well as the additive model as shown by the test of directed separation (model 1, see Table 1), but explained a much higher proportion of the variability in multifunctionality $\left(\mathrm{R}^{2}=0.56\right.$ vs. 0.30 , Table 1$)$. In model 2, there was a positive effect of the interaction between bladderwrack and rooted vegetation cover on multifunctionality $(p<0.001)$. The interaction was a result of a synergistic effect (Figure 6): multifunctionality increased more steeply with higher cover of both rooted vegetation and bladderwrack together, than by rooted vegetation alone (Figure 7 and Figure S3). For example, when rooted vegetation cover was $30 \%$, multifunctionality was 0.741 when bladderwrack cover was $10 \%$, but 0.995 when bladderwrack cover was $40 \%$. The interaction was the second strongest effect in the two models (standardized coefficient: 1.18), following a positive effect of bay area on species richness of rooted vegetation (standardized coefficient: 1.45). There was also a marginally significant negative effect of land-derived nitrogen load on multifunctionality (Figure 6, $p=0.055$ ). Bladderwrack cover increased with topographic openness, while rooted vegetation cover increased with species richness of rooted vegetation. There was a trend toward a negative effect of bladderwrack cover on species richness of rooted vegetation (Figure 6, $p=0.072$ ), and a trend toward a negative effect of topographic openness on rooted vegetation cover (Figure 6, $p=0.073$ ), but there was no statistically significant effect of topographic openness on species richness of rooted vegetation.

In the additive model (model 1 effects) multifunctionality increased with cover of bladderwrack and rooted vegetation (Table 1, Figure S4 and Figure S5). Here, the negative effect of land-derived nitrogen load on multifunctionality was also marginally significant $(p=0.051)$ and comparable in strength to the positive effects of bladderwrack and rooted vegetation cover (Table 1, Figure S4 and Figure S5). The remaining paths did not differ from model 2.

The weighted multifunctionality models largely confirmed the results of the original (unweighted) model. Accordingly, also in the weighted analyses a higher proportion of the multifunctionality was explained in models including the interaction, than in the additive models (Table 1), and models did not differ in terms of AIC ( $\Delta$ AIC $<4$ units). In the weighted models with higher influence of large predatory fish recruitment, or 'nuisance' algal biomass, the interactive effect of bladderwrack and rooted vegetation cover on multifunctionality was slightly stronger than in the original model (standardized coefficient: 1.27 and 1.30 vs. 1.18). When instead the influence of water clarity was increased, the additive effects of bladderwrack and rooted vegetation cover on multifunctionality in model 1 increased in strength. Finally, when the influence of water clarity or grazer biomass were increased, the negative effect of land-derived nitrogen load on multifunctionality became significant (compared to marginally significant), both in model 1 and 2. For a more detailed description of the results from the weighted multifunctionality models see Text S1.

\section{Discussion}

The aim of this study was to assess the relative importance of species richness and cover of rooted aquatic vegetation, together with cover of drift wrack, for ecosystem multifunctionality in temperate shallow coastal bays. We found that high cover of rooted vegetation and high cover of bladderwrack (mainly loose-lying and drifting) had a synergistic effect on multifunctionality. This synergy appeared especially important for large predatory fish recruitment and the filamentous algal biomass, whereas water clarity was more influenced by the additive effects of bladderwrack and rooted vegetation cover. The rooted vegetation cover was driven by the species richness of vegetation, while bladderwrack cover was driven by bay openness (wave exposure and water exchange). In contrast to the positive vegetation effects on multifunctionality, there was a direct negative effect of land-derived nitrogen on multifunctionality; an effect that increased in strength when water clarity or grazer biomass was given more importance to multifunctionality.

Our results suggest that the species richness of the vegetation had an indirect positive effect on multifunctionality, by increasing the cumulative 


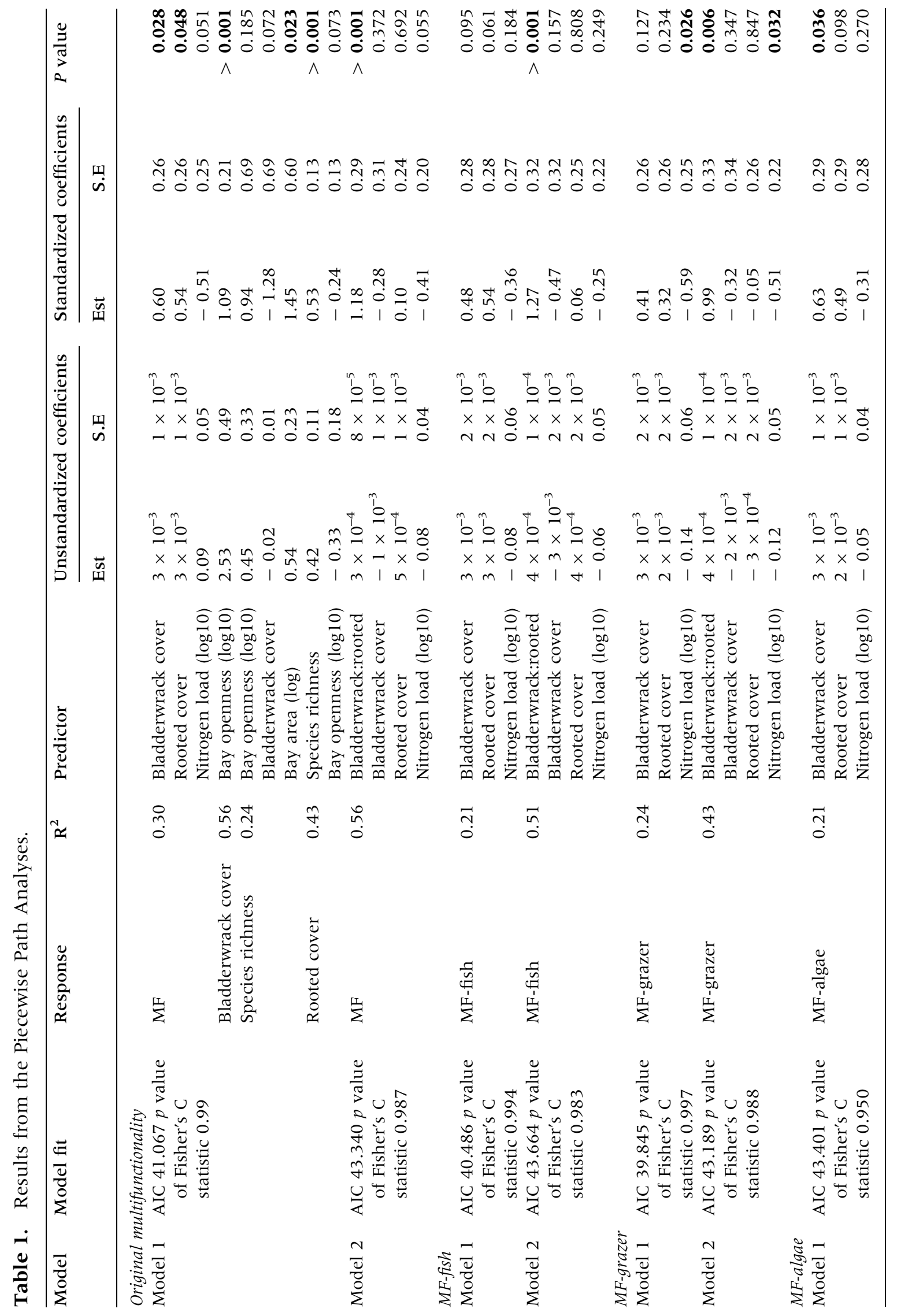




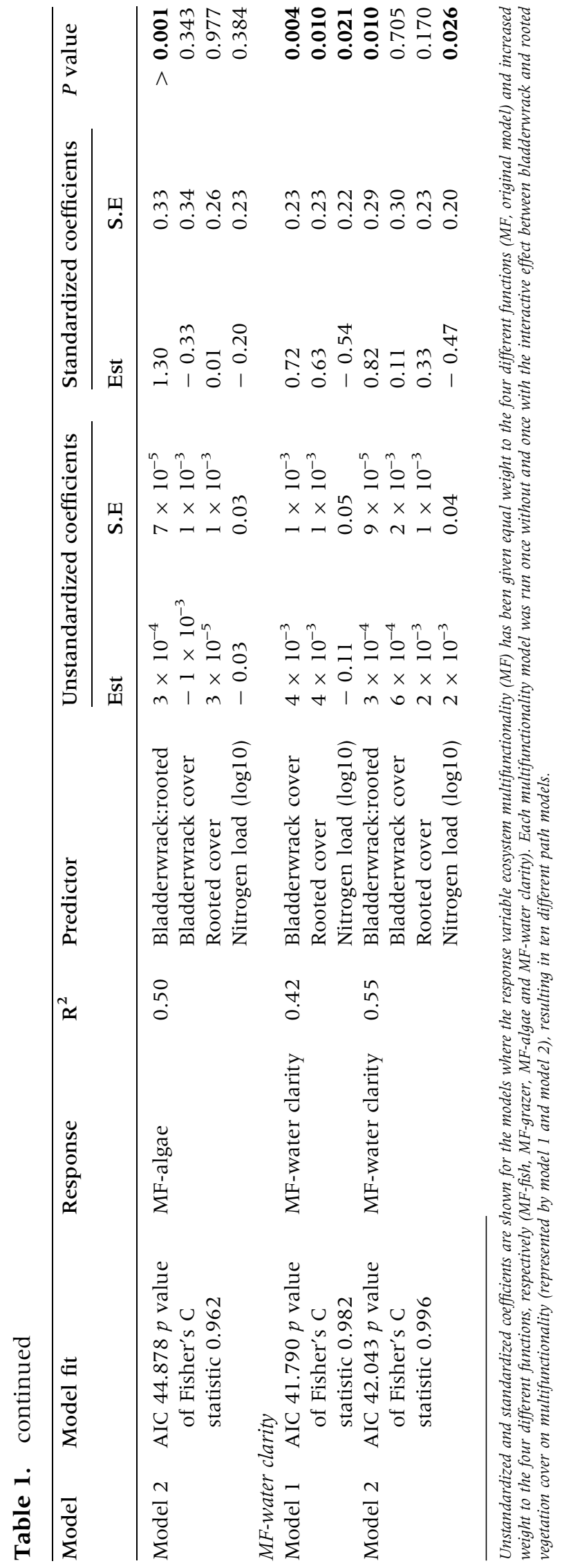

vegetation cover. Plant species richness has been experimentally shown to increase plant cover and biomass in hundreds of experiments (reviewed by Cardinale and others 2011). The positive effect of species richness on rooted vegetation cover in our study, combined with a lack of a statistically significant direct effect of richness on multifunctionality, indicates that rare species are important for achieving high cover, even though they do not contribute directly to multifunctionality (see also Gamfeldt and Roger 2017). Plant cover is a key composite plant trait often linked to ecosystem structure and function in coastal ecosystems (for example, Pillay and others 2010). Species richness has often been found to predict multifunctionality (Lefcheck and others 2015), but had no direct effect in this study (see also review by van der Plas 2019). The lack of a direct diversity effect on multifunctionality could be caused by a few dominant species sustaining high multifunctionality, whereas a high vegetation diversity allows more complete use of the substrate and therefore increases vegetation cover. The three most common rooted vegetation species in our study were Stuckenia pectinata, Potamogeton perfoliatus, and Myriophyllum spicatum (occurring in 29, 24 and 22 of the 32 bays, respectively, Table S1). They are all dominant, canopy-forming and competitive species with shoots reaching up to $3 \mathrm{~m}$ from the seabed (unpublished data), forming structurally complex underwater 'jungles.' Viewed together, these results suggest that both vegetation diversity and identity benefit the functioning of these shallow, coastal ecosystems.

High cover of loose-lying and drifting bladderwrack also increased multifunctionality, particularly when combined with high cover of rooted vegetation (interaction effect; see model 2, Figure 6). This synergistic effect suggests that wrack and rooted vegetation complement each other functionally, potentially because high habitat volume, surface area, complexity and height cannot be achieved by high wrack or high rooted vegetation cover alone. But when the two vegetation types co-occur, a more complex and (locally) variable habitat is created, allowing different species and life stages to find refuge, spawn or feed. The importance of the synergistic effect on associated consumers is supported by our findings that the synergy increased in strength when increasing the contribution of either large predatory fish recruitment and biomass of filamentous algae to multifunctionality (Table 1). Further, when increasing the contribution of grazer biomass, the additive effects of bladderwrack and rooted vege- 


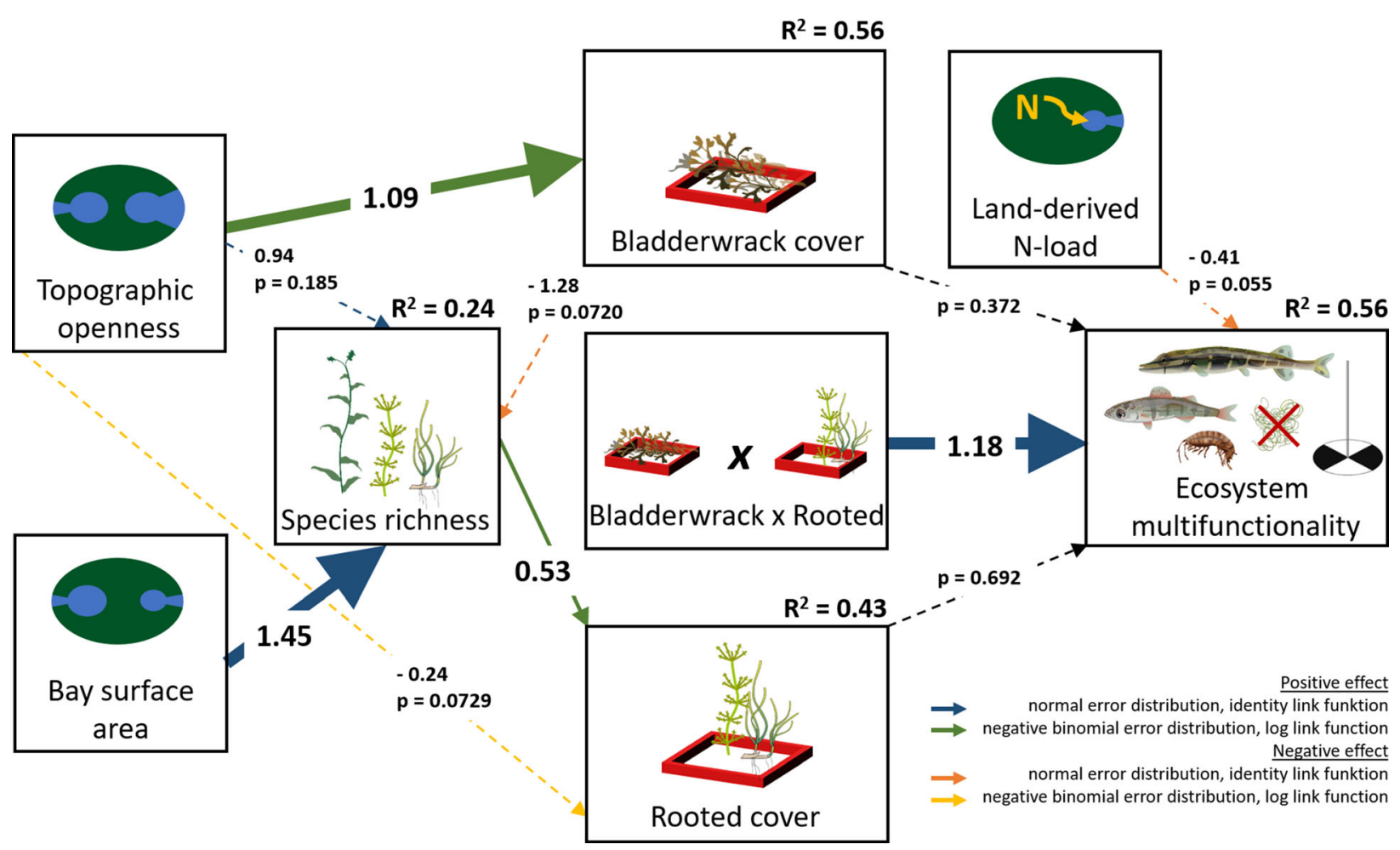

Figure 6. Path diagram of model 2 with the interaction between bladderwrack and rooted vegetation cover. The width of the arrows is proportional to the standardized coefficients (also shown in numbers next to arrows). Significance level was set at alpha $=0.05$. Nonsignificant relationships are indicated with dashed arrows.

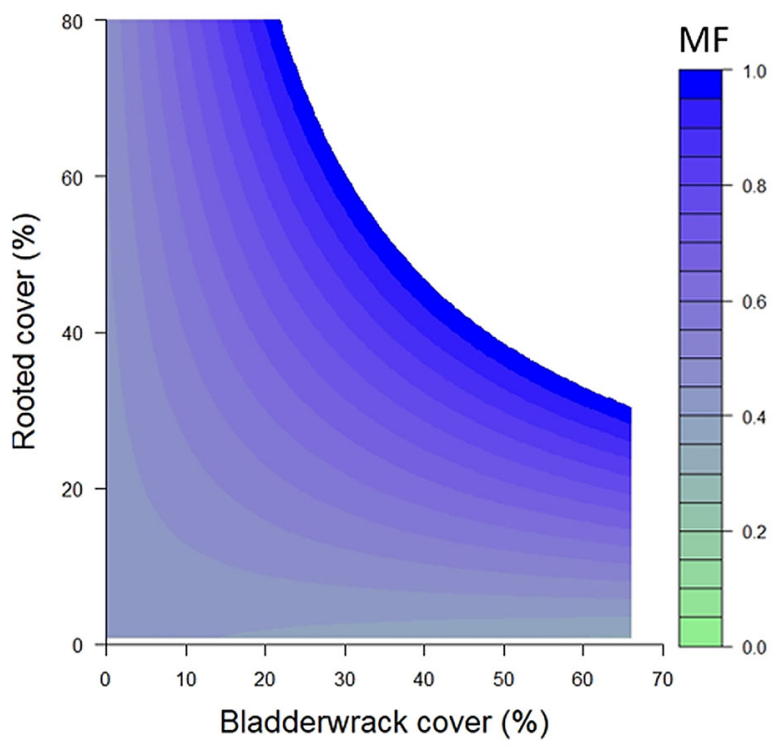

Figure 7. Interactive effect between bladderwrack cover and rooted vegetation cover on multifunctionality (MF). The positive effect of rooted vegetation cover increases with increased cover of bladderwrack and vice versa. This interactive effect is also shown in Figure S3, together with the data points. tation cover on multifunctionality disappeared, while their synergistic (interactive) effect remained. This reflects the importance of the highly complex and variable habitat also for grazers. In contrast, water clarity was mainly explained by the additive effects of high rooted vegetation and bladderwrack cover (Table 1). This is in line with previous studies showing the importance of total vegetation cover for increased competition with phytoplankton, increased sedimentation and decreased re-suspension (Austin and others 2017). In summary, this plant-wrack synergy effect constitutes a form of higher-order, macrophyte functional diversity effect that complements the aforementioned indirect positive influence of rooted vegetation diversity on multifunctionality.

Besides the direct positive effect of bladderwrack cover on multifunctionality, there was also a trend toward a negative effect of bladderwrack cover on species richness and cover of rooted vegetation, which would indirectly reduce multifunctionality. We speculate that while drift wrack and rooted vegetation complement each other functionally (see above), they can also compete for limiting resources such as light and space. Previous studies suggest there may be a threshold in rooted vege- 
tation density, beyond which the rooted vegetation is dense or tall enough to survive and continue to grow in the presence of drifting wrack (Moksnes and others 2018). However, small and/or sensitive species (such as Chara aspera, Chara globularis, and Ruppia cirrhosa), or sparsely growing meadows are likely to be more severely affected by drift wrack. This could explain the near-significant trend of a decrease in rooted vegetation species richness with increasing bladderwrack cover, instead of a direct effect of bladderwrack on rooted vegetation cover. Drift wrack has previously been found to hinder seagrass restoration by outcompeting underlying seagrass shoots, but if the seagrass instead grows densely, the wrack stays at the edges of the meadow (Valdemarsen and others 2010; Moksnes and others 2018). Our findings indicate similar competitive interactions in shallow Baltic Sea bays, which probably manifest in spring when the rooted vegetation is generally sparser and smaller. However, the direct positive influence of drift wrack on multifunctionality suggests that drift wrack may compensate for its indirect negative effect on multifunctionality, by in itself forming an important habitat. Consequently, the relationship between drift wrack and ecosystem processes and services can be much more complex than the often-observed negative impacts of more common mats of filamentous drift algae (Hauxwell and others 2001). Additionally, the abundance of drift wrack in our study is more likely driven by water movement alone (reflected by topographic openness), in contrast to the filamentous algae that are influenced by both wave action and high nutrient loading (Fletcher 1996; Berglund and others 2003). Hence, reducing eutrophication should in theory increase the amount of drift bladderwrack through increased light penetration, as opposed to reducing drifting nuisance algae. However, the persistence of drift wrack beds, particularly in relation to rooted vegetation, must be studied in greater detail.

The direct negative effect of land-derived nutrient load on multifunctionality suggests that eutrophication has negative effects not just on single ecosystem components, but on the entire ecosystem functioning. Simultaneously, this finding indicates that measures that reduce eutrophication may increase multifunctionality. Regulation of fisheries may have similar effects on fish communities as eutrophication mitigation measures, as shown in the Baltic Sea where fishing targeting large predatory fish has been found to generate eutrophication-like effects (Eriksson and others 2011; Bergström and others 2019). Moreover, protecting rooted vegetation against effects of, for example, dredging and recreational boating (Short and Wyllie-Eciieverria 1996; Hansen and others 2019) is important to maintain or increase multifunctionality, since high species richness and cover of vegetation counteracts the negative effect of nitrogen load on multifunctionality.

In conclusion, this study links ecological theory with management applications by illustrating how the diversity and abundance of habitat-forming aquatic vegetation jointly affect ecosystem multifunctionality. We estimated multifunctionality based on four functions tightly linked to ecosystem services such as food provisioning, recreation, maintenance of biodiversity and habitats, and biological regulation in coastal areas of the Baltic Sea (HELCOM 2010). These ecosystems have been classified as having bad or moderate status in the study area, where excess nutrient loading and commercial fishing are anthropogenic drivers with large negative net effects on habitats and primary production (Bryhn and others 2015, 2020). Other anthropogenic pressures in these shallow coastal ecosystems include recreational boating, mooring structures and shoreline development (Sundblad and Bergström 2014; Sagerman and others 2020). To balance the human use and exploitation of coastal ecosystems and the maintenance of ecosystem services, we need a better understanding of the contribution of coastal habitats to ecosystem services in environmental decision making, where the use of an ecosystem-based approach is increasing (Kosenius and Ollikainen 2015). Many people that live near the coast value habitatforming vegetation, conservation of pristine areas and large stocks of predatory fish (Kosenius and Ollikainen 2015), whereas others find dense and high submerged vegetation to be a nuisance that clogs waterways (van Nes and others 2002, Sandström and others 2005). Our results indirectly suggest that protecting high vegetation diversity may counteract the negative effects on multifunctionality imposed by anthropogenic pressures such as increasing nutrient load. The positive effects of the diversity-driven rooted vegetation cover and drift wrack on ecosystem multifunctionality were of equal or greater strength (additive vs. synergistic effects) than the negative effect of nutrient load, indicating the importance of aquatic vegetation for healthy and highly valuable coastal ecosystems.

\section{ACKNOWLEDGEMENTS}

We thank the property and fishing right owners around each bay for facilitating the field work; E. Anderberg, F. Ek, P. Jacobson, G. Johansson, C. 
Jönander, E. Mörk, L. Näslund, O. Pettersson, M. van Regteren, G. Lilliesköld Sjöö, J. Sagerman, S. Skoglund, M. van der Snoek, V. Thunell and L. Vik for assistance in the field and laboratory; JB. Grace, JS. Lefcheck and JEK. Byrnes for statistical advice; and two anonymous reviewers for helpful comments on an earlier draft.

\section{FUNDING}

Open access funding was provided by Stockholm University. This study is a product of project PlantFish and was funded by Formas (grant 2013-1074), HM Carl XVI Gustaf's Foundation for Science and Education (2014-0002), the Baltic Sea 2020 foundation and the Baltic Sea Centre (Askö grants).

\section{DATA ACCESSIBILITY}

The data used for the manuscript are included as electronic supplemental material including complete metadata (Appendix 1).

\section{Compliance with Ethical Standards}

Ethical Approval The fish sampling procedures were judged and approved by the Ethical Board on Animal Experiments of the County Court of Uppsala, Sweden, permit C 139/13 (to the Department of Aquatic Resources, Swedish University of Agricultural Sciences).

Conflict of interest The authors declare that they have no conflict of interest.

\section{OPEN ACCESS}

This article is licensed under a Creative Commons Attribution 4.0 International License, which permits use, sharing, adaptation, distribution and reproduction in any medium or format, as long as you give appropriate credit to the original author(s) and the source, provide a link to the Creative Commons licence, and indicate if changes were made. The images or other third party material in this article are included in the article's Creative Commons licence, unless indicated otherwise in a credit line to the material. If material is not included in the article's Creative Commons licence and your intended use is not permitted by statutory regulation or exceeds the permitted use, you will need to obtain permission directly from the copyright holder. To view a copy of this licence, visit $h$ ttp://creativecommons.org/licenses/by/4.0/.

\section{REFERENCES}

Agawin NSR, Duarte CM. 2002. Evidence of direct particle trapping by a tropical seagrass meadow. Estuaries 25:12051209.

Arheimer B, Dahne J, Donnelly C, Lindström G, Strömqvist J. 2012. Water and nutrient simulations using the HYPE model for Sweden vs. the Baltic Sea basin - influence of input-data quality and scale. Hydrology Research 43:315-329.

Austin ÅN, Hansen JP, Donadi S, Eklöf JS. 2017. Relationships between aquatic vegetation and water turbidity: A field survey across seasons and spatial scales. PLoS ONE 12:e0181419.

Berglund J, Mattila J, Rönnberg O, Heikkilä J, Bonsdorff E. 2003. Seasonal and inter-annual variation in occurrence and biomass of rooted macrophytes and drift algae in shallow bays. Estuarine Coastal and Shelf Science 56:1167-1175.

Bergström L, Karlsson M, Bergström U, Pihl L, Kraufvelin P. 2019. Relative impacts of fishing and eutrophication on coastal fish assessed by comparing a no-take area with an environmental gradient. Ambio 48:565-579.

Berkström C, Wennerström L, Bergström U. 2019. Ekologisk konnektivitet i svenska kust- och havsområden - en kunskapssammanställning. Aqua reports No 2019:15, Swedish University of Agricultural Sciences, Institute of Aquatic Resources.

Bryhn A, Kraufvelin P, Bergström U, Vretborn M, Bergström L. 2020. A Model for Disentangling Dependencies and Impacts among Human Activities and Marine Ecosystem Services. Environmental Management 65:575-586.

Bryhn A, Lindegarth M, Bergström L, Bergström U. 2015. Ekosystemtjänster från svenska hav: Status och påverkansfaktorer. Swedish Agency for Marine and Water Management's report No 2015:12.

Burnham KP, Anderson DR, Huyvaert KP. 2011. AIC model selection and multimodel inference in behavioral ecology: some background, observations, and comparisons. Behavioral Ecology and Sociobiology 65:23-35.

Byrnes JEK, Gamfeldt L, Isbell F, Lefcheck JS, Griffin JN, Hector A, Cardinale BJ, Hooper DU, Dee LE, Duffy JE. 2014. Investigating the relationship between biodiversity and ecosystem multifunctionality: challenges and solutions. Methods in Ecology and Evolution 5:111-124.

Cardinale BJ, Matulich KL, Hooper D, Byrnes JEK, Duffy E, Gamfeldt L, Balvanera P, O'Connor M, Gonzales A. 2011. The functional role of producer diversity in ecosystems. American Journal of Botany 98:572-592.

de Boer WF. 2007. Seagrass - sediment interactions, positive feedbacks and critical thresholds for occurrence: a review. Hydrobiologia 591:5-24.

Deegan LA, Wright A, Ayvazian SG, Finn JT, Golden H, Merson RR, Harrison J. 2002. Nitrogen loading alters seagrass ecosystem structure and support of higher trophic levels. Aquatic Conservation: Marine and Freshwater Ecosystems 12:193-212.

Dempster T, Kingsford MJ. 2004. Drifting objects as habitat for pelagic juvenile fish off New South Wales, Australia. Marine and Freshwater Research 55:675-687.

Donadi S, Austin ÅN, Bergström U, Eriksson BK, Hansen JP, Jacobson P, Sundblad G, van Regteren M, Eklöf JS. 2017. A cross-scale trophic cascade from large predatory fish to algae in coastal ecosystems. Proceedings of the Royal Society B: Biological Sciences 284:20170045. 
Donadi S, Austin ÅN, Svartgren E, Eriksson BK, Hansen JP, Eklöf JS. 2018. Density-dependent positive feedbacks buffer aquatic plants from interactive effects of eutrophication and predator loss. Ecology 99:2515-2524.

Duarte CM. 2000. Marine biodiversity and ecosystem services: An elusive link. Journal of Experimental Marine Biology and Ecology 250:117-131.

Duffy JE, Hughes AR, Moksnes P-O. 2013. Ecology of seagrass communities. In: Bertness MD, Bruno JF, Silliman BR, Stachowicz JJ, Eds. Marine Community Ecology and Conservation, Massachusetts: Sinauer Associates Inc. pp 271-297.

Eklöf J, Austin Å, Bergström U, Donadi S, Eriksson BDHK, Hansen JP, Sundblad G. 2017. Size matters: relationships between body size and body mass of common coastal, aquatic invertebrates in the Baltic Sea. PeerJ 5:e2906.

Elmgren R. 1989. Man's impact on the ecosystem of the Baltic Sea: Energy flows today and at the turn of the century. Ambio 18:326-332.

Eriksson BK, Sieben K, Eklö J, Ljunggren L, Olsson J, Casini M, Bergström U. 2011. Effects of Altered Offshore Food Webs on Coastal Ecosystems Emphasize the Need for Cross-Ecosystem Management. Ambio 40:786-797.

Fletcher RL. 1996. The occurence of 'green tides' - a review. In: Schramm W, Nienhuis PH, Eds. Marine Benthic Vegetation-Recent Changes and the Effects of Eutrophication. Vol. 123. Heidelberg: Springer. pp 7-43.

Gamfeldt L, Hillebrand H, Jonsson PR. 2008. Multiple functions increase the importance of biodiversity for overall ecosystem functioning. Ecology 89:1223-1231.

Gamfeldt L, Roger F. 2017. Revisiting the biodiversity - ecosystem multifunctionality relationship. Nature Ecology and Evolution 1:0168.

Garland G, Banerjee S, Edlinger A, Miranda Oliveira E, Herzog C, Wittwer R, Philippot L, Maestre FT, Heijden MGA. 2020. A closer look at the functions behind ecosystem multifunctionality: A review. Early view in Journal of Ecology.

Grace JB, Anderson TM, Olff H, Scheiner SM. 2010. On the specification of structural equation models for ecological systems. Ecological Monographs 80:67-87.

Grace JB, Johnson DJ, Lefcheck JS, Byrnes JEK. 2018. Quantifying relative importance: computing standardized effects in models with binary outcomes. Ecosphere 9:e02283.

Gustafsson BG, Schenk F, Blenckner T, Eilola K, Meier HEM, Müller-Karulis B, Neumann T, Ruoho-Airola T, Savchuk OP, Zorita E. 2012. Reconstructing the development of Baltic Sea eutrophication 1850-2006. Ambio 41:534-548.

Hansen JP. 2016. Uppföljning av bottenvegetation i grunda Österjövikar - varians och precisionsanalyser med visuella metoder genom snorkling. Swedish Insitute for the Marine Environment's Report No 2016:2.

Hansen JP, Sundblad G, Bergström U, Austin ÅN, Donadi S, Eriksson BK, Eklöf JS. 2019. Recreational boating degrades vegetation important for fish recruitment. Ambio 48:539-551.

Hansen JP, Wikström SA, Kautsky L. 2008. Effects of water exchange and vegetation on the macroinvertebrate fauna composition of shallow land-uplift bays in the Baltic Sea. Estuarine, Coastal and Shelf Science 77:535-547.

Hauxwell J, Cebrián J, Furlong C, Valiela I. 2001. Macroalgal canopies contribute to eelgrass (Zostera marina) decline in temperate estuarine ecosystems. Ecology 82:1007-1022.

Hector A, Bagchi R. 2007. Biodiversity and ecosystem multifunctionality. Nature 448:188-190.
HELCOM. 2010. Ecosystem Health of the Baltic Sea 2003-2007: HELCOM Initial Holistic Assessment. Baltic Sea Environment Proc No 122.

HELCOM. 2013a. Biotope information sheet. HELCOM Red List Biotope Expert Group.

HELCOM. 2013b. Red List of Baltic Sea underwater biotopes, habitats and biotope complexes. Baltic Sea Environmental Proceedings No 138.

Isbell F, Calcagno V, Hector A, Connolly J, Harpole WS, Reich PB, Scherer-Lorenzen M, Schmid B, Tilman D, van Ruijven J, Weigelt A, Wilsey BJ, Zavaleta ES, Loreau M. 2011. High plant diversity is needed to maintain ecosystem services. Nature 477:199-202.

Kosenius A-K, Ollikainen M. 2015. Ecosystem benefits from coastal habitats - A three-country choice experiment. Marine Policy 58:15-27.

Krause-Jensen D, Sagert S, Schubert H, Boström C. 2008. Empirical relationships linking distribution and abundance of marine vegetation to eutrophication. Ecological Indicators 8:515-529.

Le Bagousse-Pinguet Y, Liancourt P, Gross N, Straile D. 2012. Indirect facilitation promotes macrophyte survival and growth in freshwater ecosystems threatened by eutrophication. Journal of Ecology 100:530-538.

Lefcheck JS. 2016. piecewiseSEM: Piecewise structural equation modeling in $\mathrm{R}$ for ecology, evolution, and systematics. Methods in Ecology and Evolution 7:573-579.

Lefcheck JS, Byrnes JEK, Isbell F, Gamfeldt L, Griffin JN, Eisenhauer N, Hensel MJS, Hector A, Cardinale BJ, Duffy JE. 2015. Biodiversity enhances ecosystem multifunctionality across trophic levels and habitats. Nature Communications 6:6936.

Lefcheck JS, Orth RJ, Dennison WC, Wilcox DJ, Murphy RR, Keisman J, Gurbisz C, Hannam M, Landry JB, Moore KA, Patrick CJ, Testa J, Weller DE, Batiuk RA. 2018. Long-term nutrient reductions lead to the unprecedented recovery of a temperate coastal region. Proceedings of the National Academy of Sciences 115:3658-3662.

Levin PS, Fogarty MJ, Murawski SA, Fluharty D. 2009. Integrated ecosystem assessments: Developing the scientific basis for ecosystem-based management of the ocean. PLoS Biology 7:e1000014.

Lotze HK, Lenihan HS, Bourque BJ, Bradbury RH, Cooke RG, Kay MC, Kidwell SM, Kirby MX, Peterson CH, Jackson JBC. 2006. Depletion, Degradation, and Recovery Potential of Estuaries and Coastal Seas. Science 312:1806-1809.

Madsen JD, Chambers PA, James WF, Koch EW, Westlake DF. 2001. The interaction between water movement, sediment dynamics and submersed macrophytes. Hydrobiologia 444:71-84.

Maestre FT, Quero JL, Gotelli NJ, Escudero A, Ochoa V, Delgado-Baquerizo M, García-Gómez M, Bowker MA, Soliveres S, Escolar C, García-Palacios P, Berdugo M, Valencia E, Gozalo B, Gallardo A, Aguilera L, Arredondo T, Blones J, Boeken B, Bran D, Conceição AA, Cabrera O, Chaieb M, Derak M, Eldridge DJ, Espinosa CI, Florentino A, Gaitán J, Gatica MG, Ghiloufi W, Gómez-González S, Gutiérrez JR, Hernández RM, Huang X, Huber-Sannwald E, Jankju M, Miriti M, Monerris J, Mau RL, Morici E, Naseri K, Ospina A, Polo V, Prina A, Pucheta E, Ramírez-Collantes DA, Romão R, Tighe M, TorresDíaz C, Val J, Veiga JP, Wang D, Zaady E. 2012. Plant Species Richness and Ecosystem Multifunctionality in Global Drylands. Science 335:214-219. 
Manning P, van der Plas F, Soliveres S, Allan E, Maestre FT, Mace G, Whittingham MJ, Fischer M. 2018. Redefining ecosystem multifunctionality. Nature Ecology and Evolution 2:427-436.

McGlathery KJ, Sundbäck K, Anderson IC. 2007. Eutrophication in shallow coastal bays and lagoons: the role of plants in the coastal filter. Marine Ecology Progress Series 348:1-18.

Meyer ST, Ptacnik R, Hillebrand H, Bessler H, Buchmann N, Ebeling A, Eisenhauer N, Engels C, Fischer M, Halle S, Klein A-M, Oelmann Y, Roscher C, Rottstock T, Scherber C, Scheu S, Schmid B, Schulze E-D, Temperton VM, Tscharntke T, Voigt W, Weigelt A, Wilcke W, Weisser WW. 2018. Biodiversitymultifunctionality relationships depend on identity and number of measured functions. Nature Ecology $\&$ Evolution 2:44-49.

Moksnes PO, Eriander L, Infantes E, Holmer M. 2018. Local Regime Shifts Prevent Natural Recovery and Restoration of Lost Eelgrass Beds Along the Swedish West Coast. Estuaries and Coasts 41:1712-1731.

Orth RJ, Carruthers TJB, Dennison WC, Duarte CM, Fourqurean JW, Heck KL Jr, Hughes AR, Kendrick GA, Kenworthy WJ, Olysrink S, Short FT, Waycott M, Williams SL. 2006. A Global Crisis for Seagrass Ecosystems. BioScience 56:987-997.

Persson J, Håkanson L, Pilesjo P. 1994. Prediction of surface water turnover time in coastal waters using digital bathymetric information. Environmetrics 5:433-449.

Pillay D, Branch GM, Griffiths CL, Williams C, Prinsloo A. 2010. Ecosystem change in a South African marine reserve (19602009): Role of seagrass loss and anthropogenic disturbance. Marine Ecology Progress Series 415:35-48.

van der Plas F. 2019. Biodiversity and ecosystem functioning. Biological Reviews 19:1220-1245.

R Core Team. 2018. R: A language and environment for statistical computing. https://www.r-project.org/

Rosenzweig ML. 1995. Species diversity in space and time. Cambridge University Press 436p.

Rosqvist K, Mattila J, Sandström A, Snickars M, Westerbom M. 2010. Regime shifts in vegetation composition of Baltic Sea coastal lagoons. Aquatic Botany 93:39-46.

Sagerman J, Hansen JP, Wikström SA. 2020. Effects of boat traffic and mooring infrastructure on aquatic vegetation: A systematic review and meta-analysis. Ambio 49:517-530.

Sand-Jensen K, Lagergaard Pedersen N, Thorsgaard I, Moeslund B, Borum J, Brodersen KP. 2008. 100 years of vegetation decline and recovery in Lake Fure, Denmark. Journal of Ecology 96:260-271.

Sanderson MA, Skinner RH, Barker DJ, Edwards GR, Tracy BF, Wedin DA. 2004. Plant Species Diversity and Management of Temperate Forage and Grazing Land Ecosystems. Crop Science 44:1132-1144.

Sandström A, Eriksson BK, Karås P, Isæus M, Schreiber H. 2005. Boating and Navigation Activities Influence the Recruitment of Fish in a Baltic Sea Archipelago Area. Ambio 34(2):125130 .

Saulamo K, Neuman E. 2002. Local management of Baltic fish stocks - significance of migrations. The Swedish National Board of Fisheries Report No 2002:9.

Scheffer M. 2004. Ecology of Shallow Lakes. (DeAngelis DL, Manly BFJ, editors.). (First edition 1998): Springer

Schramm W, Nienhuis PH, Eds. 1996. Marine benthic vegetation: recent changes and the effects of eutrophication. Heidelberg, Germany: Springer.
Shipley B. 2000. Cause and Correlation in Biology: A user's guide to path analysis, structural equations and causal inference. Cambridge University Press 336p.

Shipley B. 2009. Confirmatory path analysis in a generalized multilevel context. Ecology 90:363-368.

Shipley B. 2013. The AIC model selection method applied to path analytic models compared using a d-separation test. Ecology 94:560-564.

Short FT, Wyllie-Eciieverria S. 1996. Natural and human-induced disturbance of seagrasses. Environmental Conservation 23:17-27.

Snickars M, Sandström A, Lappalainen A, Mattila J. 2007. Evaluation of low impact pressure waves as a quantitative sampling method for small fish in shallow water. Journal of Experimental Marine Biology and Ecology 343:138-147.

Snickars M, Sandström A, Lappalainen A, Mattila J, Rosqvist K, Urho L. 2009. Fish assemblages in coastal lagoons in landuplift succession: The relative importance of local and regional environmental gradients. Estuarine, Coastal and Shelf Science 81:247-256.

Snickars M, Sundblad G, Sandström A, Ljunggren L, Bergström U, Johansson G, Mattila J. 2010. Habitat selectivity of substrate-spawning fish: Modelling requirements for the Eurasian perch Perca fluviatilis. Marine Ecology Progress Series 398:235-243.

Soliveres S, van der Plas F, Manning P, Prati D, Gossner MM, Renner SC, Alt F, Arndt H, Baumgartner V, Binkenstein J, Birkhofer K, Blaser S, Blüthgen N, Boch S, Böhm S, Börschig C, Buscot F, Diekötter T, Heinze J, Hözel N, Jung K, Klaus VH, Kleinebecker T, Klemmer S, Krauss J, Lange M, Morris EK, Müller J, Oelmann Y, Overmann J, Pašalić E, Rillig MC, Schaefer HM, Schloter M, Schmitt B, Schöning I, Schrumpf M, Sikorski J, Socher SA, Solly EF, Sonnemann I, Sorkau E, Steckel J, Steffan-Dewenter I, Stempfhuber B, Tschapka M, Türke M, Venter PC, Weiner CN, Weisser WW, Werner M, Westphal C, Wilcke W, Wolters V, Wubet T, Wurst S, Fischer M, Allan E. 2016. Biodiversity at multiple trophic levels is needed for ecosystem multifunctionality. Nature Publishing Group 536:456-459.

Stachowicz JJ, Graham M, Bracken MES, Szoboszlai AI. 2008. Diversity enhances cover and stability of seaweed assemblages: the role of heterogeneity and time. Ecology 89:30083019.

Steffen W, Richardson K, Rockström J, Cornell SE, Fetzer I, Bennett EM, Biggs R, Carpenter SR, de Vries W, de Wit CA, Folke C, Gerten D, Heinke J, Mace GM, Persson LM, Ramanathan V, Reyers B, Sörlin S. 2015. Planetary boundaries: Guiding human development on a changing planet. Science 347:1259855.

Sundblad G, Bergström U. 2014. Shoreline development and degradation of coastal fish reproduction habitats. Ambio 43:1020-1028.

Sundblad G, Bergström U, Sandström A, Eklöv P. 2014. Nursery habitat availability limits adult stock sizes of predatory coastal fish. ICES Journal of Marine Science 71:672-680.

Svedelius N. 1901. Studier öfver Östersjöns Hafsalgflora. Uppsala University Doctoral Thesis.

Valdemarsen T, Canal-Vergés P, Kristensen E, Holmer M, Kristiansen MD, Flindt MR. 2010. Vulnerability of Zostera marina seedlings to physical stress. Marine Ecology Progress Series 418:119-130.

Valiela I, McClelland J, Hauxwell J, Behr PJ, Hersh D, Foreman K. 1997. Macroalgal blooms in shallow estuaries: Controls and 
ecophysiological and ecosystem consequences. Limnology and Oceanography 42:1105-1118.

Van Nes E, Scheffer M, van den Berg M, Coops H. 2002. Aquatic macrophytes: restore, eradicate or is there a compromise? Aquatic Botany 72:387-403.

Wang HJ, Wang HZ, Liang XM, Pan BZ, Kosten S. 2016. Macrophyte species strongly affects changes in $\mathrm{C}, \mathrm{N}$, and $\mathrm{P}$ stocks in shallow lakes after a regime shift from macrophyte to phytoplankton dominance. Inland Waters 6:449-460.

Waycott M, Duarte CM, Carruthers TJB, Orth RJ, Dennison WC, Olyarnik S, Calladine A, Fourqurean JW, Heck KL Jr, Hughes AR, Kendrick GA, Kenworthy WJ, Short FT, Williams SL. 2009. Accelerating loss of seagrasses across the globe threatens coastal ecosystems. Proceedings of the National Academy of Sciences of the United States of America 106:12377-12381.

Werner FJ, Graiff A, Matthiessen B. 2016. Even moderate nutrient enrichment negatively adds up to global climate change effects on a habitat-forming seaweed system. Limnology and Oceanography 61:1891-1899.
Wijnbladh E, Plantman P. 2006. Oskarshamn site investigations. Primary production and respiration in shallow phyto-benthic communities. Swedish Nuclear Fuel and Waste Management Co. Report SKB P-06-303. Available at: https://www.skb.se/ publikation/1360738/P-06-303.pdf

Wikström SA, Kautsky L. 2007. Structure and diversity of invertebrate communities in the presence and absence of canopy-forming Fucus vesiculosus in the Baltic Sea. Estuarine, Coastal and Shelf Science 72:168-176.

Williams SL, Ambo-Rappe R, Sur C, Abbott JM, Limbong SR. 2017. Species richness accelerates marine ecosystem restoration in the Coral Triangle. Proceedings of the National Academy of Sciences of the United States of America 114:1198611991.

Zavaleta ES, Pasari JR, Hulvey KB, Tilman GD. 2010. Sustaining multiple ecosystem functions in grassland communities requires higher biodiversity. Proceedings of the National Academy of Sciences 107:1443-1446. 